Article

\title{
How Sustainable Are Land Use Tools? A Europe-Wide Typological Investigation
}

\author{
Alys Solly*(®), Erblin Berisha $₫$, Giancarlo Cotella $₫$ and Umberto Janin Rivolin $₫$ \\ Interuniversity Department of Regional, Urban Studies and Planning (DIST), Politecnico di Torino, 10125 Turin, \\ Italy; erblin.berisha@polito.it (E.B.); giancarlo.cotella@polito.it (G.C.); umberto.janinrivolin@polito.it (U.J.R.) \\ * Correspondence: alys.solly@polito.it
}

Received: 19 December 2019; Accepted: 6 February 2020; Published: 10 February 2020

\begin{abstract}
Sustainable land use depends on both the socio-economic processes that trigger spatial development and the effectiveness of spatial governance tools that aim to regulate these processes. The ESPON Sustainable Urbanization and land-use Practices in European Regions (SUPER) research project aims to analyze the main land-use dynamics in Europe, looking at and comparing the interventions implemented in the various countries in order to promote sustainability. In particular, a sample of 227 interventions was chosen from a total of 39 European countries. This paper analyzes them on the basis of four different variables: (i) the scale at which the interventions are conceived; (ii) the type of territories subject to them; (iii) the type of interventions; (iv) the type of instruments behind these interventions. On this basis, it develops a number of considerations concerning the effectiveness of the interventions implemented in Europe to promote more sustainable use of land.
\end{abstract}

Keywords: sustainability; urbanization; land use; spatial governance; spatial planning; ESPON

\section{Introduction}

In recent years, the development and implementation of sustainable land use practices in Europe have been the subject of various studies at both the European and national levels (e.g., [1,2], respectively). Despite the different approaches adopted by these studies, it seems that the sustainability of land use depends on the socio-economic processes that trigger spatial development, as well as on the effectiveness of the spatial governance instruments that regulate these processes. As pointed out by [3] (p. 5), in "most national settings, land-use planning instruments have been crafted in a context of land profusion and economic growth". However, the recent economic crisis and global challenges, like climate change and the preservation of natural resources, are forcing planners and economic players to explore possible alternatives to land consumption, such as brownfield (re)development, mixed-use development, urban reconversion, and densification practices.

Looking at the different interactions between the market-the relationship between land supply and demand - and the state - the institutional system of land-use regulations-a number of authors have contributed to the identification of the main urbanization processes that have characterized the European context in recent decades [4], in relation to the evolution of the socio-economic macro-trends [5,6]. Today, urbanization processes face many challenges, such as the increasing population and the migration from rural to urban areas, which put pressure on the available urban infrastructures, questioning also their level of sustainability. According to the European Environmental Agency, over the last fifty years, urban sprawl has accompanied the development of cities across Europe; in fact, cities and towns have expanded on average by $78 \%$, whereas the population has grown by only $33 \%$. However, when it comes to the actual impacts of the differential interventions put in place in the various European countries aiming at more sustainable use of the land, the picture is more blurred. The high heterogeneity that characterize national systems of spatial governance and planning [7], and the way 
these systems interact with and evolve in response to the contextual socio-economic conditions that characterizes each country [8-11], makes providing any systematic assessment difficult. Among the variety of comparative studies on the matter [3] (p. 5), it seems that no comprehensive study exists that investigates the interventions in Europe that aim at sustainable land use.

Aiming at providing the first contribution in this direction, the authors analyze a wide and heterogeneous set of interventions put in place in European regions towards achieving a more sustainable urbanization and land use. More precisely, the scope of this contribution is to shed some light on what type of interventions are put in place in Europe to address the sustainable development of different types of territories, through what instruments are they implemented and at what scale. To do this, it builds on some of the results of the ESPON SUPER project - Sustainable Urbanization and Land-Use Practices in European Regions [12], which is set to analyze, on the one hand, the nature of urbanization processes and, on the other, to identify the more suitable instruments for sustainable land use management. In particular, the SUPER project seeks to analyze the degree of success of the interventions affecting urbanization, such as (spatial) strategies, instruments, and mechanisms (financial, fiscal, and economic), from the European to the local level. More specifically, the study aims to understand how the interventions affect development practices, and hence, land-use changes [13] (p. 1).

After this brief introduction, the second section presents the theoretical framework of the SUPER project. The third section then focuses on the methodology adopted for the collection and classification of 227 interventions from 39 countries (28 member states of the European Union, plus Iceland, Liechtenstein, Norway and Switzerland, the countries of the Western Balkan Region and Turkey). These interventions are evaluated in the fourth section in relation to (i) the scale of interest, hence their pertinence to different territorial levels (NUTS 0,1,2,3 and LAU 1,2); (ii) the type of territory-identifying its diverse nature such as urban, rural, functional area, coastal area, mountain region, peripheral border, cross-border, scarcely populated; (iii) the type of intervention-densification, containment, regeneration of unused/problematic sites, governance, spatial quality, sectoral policy like transport, environment, and rural development; (iv) the type of instrument-legal device, land-use regulation, strategy, program, project, and subsidy. In the fifth section, the main messages of the contribution are brought forward, and some final considerations are developed regarding the different effects of the analyzed interventions. Whereas the analyzed sample of interventions does not provide room for the systematic comparison of all the countries at stake in relation to the effort they put in place towards the promotion of a more sustainable use of the land, and to the results of the latter, it certainly allows some considerations to be drawn on their differential effectiveness and aims at constituting a source of inspiration for future research on the matter.

\section{Towards a More Sustainable Land Use in Europe: The ESPON SUPER Project}

The SUPER research project provides an overview of the urbanization processes and dynamics of European land use since the 2000s, starting from the assumption that "land can be used more or less sustainably through the efficient combination of functions or minimizing the often-irrevocable impacts of new uses or activities" [12] (p. 5). Through a series of qualitative and quantitative surveys, mainly based on data processed by analytical and predictive models, SUPER aims to provide possible guidelines for more sustainable use of land in Europe in line with the target of zero soil consumption of the European Commission by 2050.

The methodological model adopted by SUPER includes a series of progressive in-depth activities (Figure 1). The first step consists in identifying the factors that drive urbanization processes, such as (i) the interaction between land supply and demand as a driver of socio-economic development at the base of urbanization processes; (ii) the identification of the differences that characterize each institutional context and finally (iii) the definition of the territorial peculiarities that distinguish the European states, starting from their geographical context and from the different nature of the urbanization processes. To the analysis of trends and contextual conditions (both institutional and territorial), more in-depth considerations were added regarding the interventions observed. Today, 
the research activity has led to the classification of 227 very heterogeneous interventions in terms of type and regulative nature. The collection of the interventions was determined by the need to represent all the European national contexts and to have an articulated range of experiences in terms of sustainability objectives and degree of success. As will be further elaborated in Section 3, various experts with different scientific and academic profiles have been identified and contacted in order to carry out the analysis. The identified interventions are, therefore, representative, but not exhaustive, in describing the urbanization processes. The research envisages the addition of further considerations, to be elaborated on the basis of the analysis of 10 case studies, through which the different practices of planning and management of the territory are explored in a sustainability perspective.

The final analytical phase consists in the evaluation of the sustainability of the interventions identified in its different dimensions: ecological, economic, social, institutional, and temporal. This should make it possible to determine which types of interventions are more appropriate for sustainable land use and which ones should be managed more carefully. The research project, therefore, aims not only to shed light on the current state of the art but also, through the proposal of a set of guidelines and policy recommendations, to accompany and facilitate the definition of future sustainable land-use development policies in Europe.

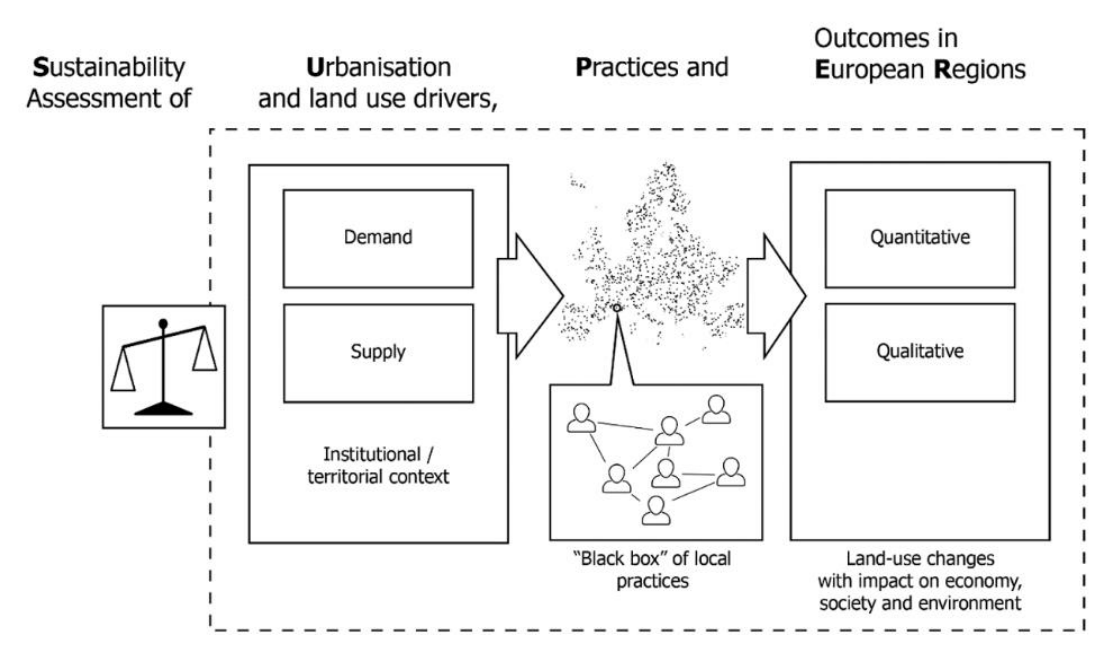

Figure 1. ESPON SUPER conceptual framework (source: [12] (p. 8)).

\section{Methodology: The Intervention Survey}

The identification of the interventions was carried out through the following methodological procedure: (i) preparation of a preliminary list of interventions by the project partners (47/227); (ii) collection of data obtained through the launch of an online questionnaire (131/227); (iii) analysis of the literature (scientific contributions, results of international research and in particular those conducted by ESPON, collection of national laws, and regulations), integration and completion of the database through further online research (49/227).

The most significant contribution, from a quantitative point of view, came from the questionnaire addressed to experts (168 respondents covering most of the European territory.-the number of interventions collected is lower than the number of respondents because the answers were not always strictly pertinent and sometimes overlapped), with different scientific and academic profiles (public universities, private and research centers) and administrative-managerial roles at different levels (EU, national, local). The questionnaire was distributed through the ESPON's network of national contacts (national contact points) and the members of the monitoring committee, as well as to the members of academic and professional associations, in particular, the Association of the European Schools of Planning (AESOP), the European Council of Spatial Planners (ECTP-CEU), the International Society of City and Regional Planners (ISOCARP). It was also distributed through a series of social 
channels and mailing lists reserved for experts in the sector, such as ResearchGate and the ESPON and AESOP newsletters.

All participants were able to express themselves, answering questions regarding the urbanization processes in their respective countries. In particular, they were asked to list up to three interventions responsible for influencing urbanization and land use (e.g., policies, regulations, subsidies, strategies, etc.), at the national, regional and local level and to provide, for each of them, the name of the intervention, the place, a brief description and an evaluation with respect to the degree of success in terms of sustainable land use.

Starting from the collected data, it was possible to compile a database of interventions that impact on sustainable land use and to progressively detail it, also thanks to the knowledge and skills of the different partners of the research team and to the careful analysis of the literature. The collected interventions were classified according to various categories (Table 1). As explained in Section 1, the scale of interest takes into consideration the various territorial and administrative units (from larger to smaller units): NUTS0 (national level), NUTS1 (major socio-economic regions), NUTS2 (basic regions for the application of regional policies), NUTS3 (small regions for specific diagnoses), LAU1 and LAU2 (municipalities and communes). The type of territory identifies the nature of the different areas: urban, rural, functional area, coastal area, mountain region, peripheral border, cross-border, and scarcely populated (categories identified in the context of the ESPON Territorial Review. See: https://territorial-review.espon.eu/report.php?type=topics\&fbclid=IwAR0z9MppYL2yD_zXFwCcVu3ixroNDvzookgvEnJQfKH10Omx7wxoYSO-Hk). The type of intervention classifies the type of initiative: densification (up-zoning, measures for infill development), containment (green belts, urban growth boundaries, etc.), regeneration (unused/problematic sites, e.g., brownfield areas), governance (cross-sectoral integration, integrated plans), spatial quality (fiscal incentives, profit sharing from development), sectoral policy like transport (transport on demand, cycle paths, etc.), environment (air, soil, and water quality), and rural development (agriculture and landscape). The type of instrument recognizes the nature of the instrument: legal device (laws, etc.), land-use regulation (zoning, local, and detail plans), strategy (masterplans, documents, and visions), program (economic measures and funds), project (spatial transformation initiatives), and subsidy (financial grants).

Each intervention was also described and assessed in relation to the results it achieved, on the basis of the categories summarized in Table 2. This assessment derives from the responses to the questionnaire, and it has been further verified through desk research. In this light, each of the 227 interventions was provided with a quantitative and qualitative assessment in relation to its success in promoting more sustainable use of land. This additional information was used to weigh the impact of the above variables in relation to one another. As will be further elaborated below, by crossing the interventions according to the identified variables, it was, therefore, possible to argue, for instance, that one or more specific types of instrument is more successful than other(s) in relation to one specific spatial scale or type of territory. 
Table 1. Categories of analysis of the interventions in the SUPER project: characteristics (source: authors' own elaboration).

\begin{tabular}{|c|c|c|c|c|c|c|c|c|c|}
\hline \multirow{3}{*}{\begin{tabular}{|c|} 
Categories \\
Period and Place of \\
Implementation \\
Scale of interest \\
\end{tabular}} & \multicolumn{9}{|c|}{ Variables } \\
\hline & \multicolumn{5}{|c|}{ Year/s implementation } & \multicolumn{4}{|c|}{ Interested country } \\
\hline & NUTSO & \multicolumn{2}{|c|}{ NUTS1 } & \multicolumn{2}{|c|}{ NUTS2 } & NUTS3 & LAU1 & LAU2 & Other \\
\hline EU level of influence & \multicolumn{3}{|c|}{ no } & \multicolumn{3}{|c|}{ yes } & \multicolumn{3}{|c|}{ If yes, how } \\
\hline Type of territory & Urban & Rural & Functional & Coastal & Mountain & Peripheral & Cross-border & Scarcely populated & Other (nation) \\
\hline Type of intervention & Densification & Containment & Regeneration & Governance & Spatial quality & Transport & Environment & Rural development & Other \\
\hline Type of instrument & Legal device & \multicolumn{2}{|c|}{ Land use regulation } & \multicolumn{2}{|c|}{ Strategy } & Program & Project & Subsidy & Other \\
\hline Regulatory status & \multicolumn{3}{|c|}{ Planned by law } & \multicolumn{3}{|c|}{ Mandatory by law } & \multicolumn{3}{|c|}{ Neither of them } \\
\hline Coercion level & \multicolumn{3}{|c|}{ Binding for all } & \multicolumn{3}{|c|}{ Binding for the public } & \multicolumn{3}{|c|}{ Not binding on anyone } \\
\hline Type of impact & \multicolumn{6}{|c|}{ Direct } & \multicolumn{2}{|c|}{ Indirect } & \\
\hline
\end{tabular}

Table 2. Categories and variables undertaken by the SUPER project: criteria for assessing the degree of success (source: authors' own elaboration).

\begin{tabular}{|c|c|c|c|c|c|}
\hline Categories & \multicolumn{5}{|c|}{ Evaluation Criteria } \\
\hline Set goals & \multicolumn{5}{|c|}{ Sustainability objectives/objectives which differ from sustainability } \\
\hline Operation & \multicolumn{5}{|c|}{ General description of how the intervention works in practice and influences land use } \\
\hline Degree of success respect to the objective of the intervention & $\begin{array}{c}\text { Unsuccessful } \\
1\end{array}$ & $\begin{array}{c}\text { Scarcely successful } \\
2\end{array}$ & $\begin{array}{c}\text { Mixed success } \\
3\end{array}$ & $\begin{array}{c}\text { Almost successful } \\
4\end{array}$ & $\begin{array}{c}\text { Successful } \\
5\end{array}$ \\
\hline Degree of success with respect to the sustainability objective & $\begin{array}{c}\text { Unsuccessful } \\
1 \\
\end{array}$ & $\begin{array}{c}\text { Scarcely successful } \\
2 \\
\end{array}$ & $\begin{array}{c}\text { Mixed success } \\
3 \\
\end{array}$ & $\begin{array}{c}\text { Almost successful } \\
4 \\
\end{array}$ & $\begin{array}{c}\text { Successful } \\
5\end{array}$ \\
\hline Temporal sustainability & \multicolumn{5}{|c|}{ Does the intervention prevent the economic, social, or environmental costs from being transferred to future generations? } \\
\hline Thematic sustainability & \multicolumn{4}{|c|}{ The intervention promotes values in the economic, social, or environmental dimension } & \\
\hline Institutional sustainability & \multicolumn{4}{|c|}{ The intervention itself is financially and politically sustainable over time } & \\
\hline Impact quality & effectiveness & & & & \\
\hline
\end{tabular}


Before proceeding with the discussion of the results of the analysis, it is important to highlight some of its limits. First of all, whereas the 227 interventions concern all the 39 countries at stake, their distribution is quantitatively uneven (see Figure 2). Of the 227 interventions considered, the highest number concerns territories located in Italy (22 interventions), followed by the Netherlands, Spain, Poland (14 interventions each), and then by all the others. Moreover, as already observed in Section 2, the identified sample is typologically heterogeneous, with the collected interventions that are representative, but not exhaustive, in describing the various urbanization processes. Nevertheless, the collection of interventions does represent all the European countries and does provide an overview of the recent and current interventions, in terms of sustainable objectives and degree of success. It is hoped that future studies will carry out more in-depth analyses and exemplification, increasing the number of interventions for all countries, providing room for a more uniform and harmonious classification.

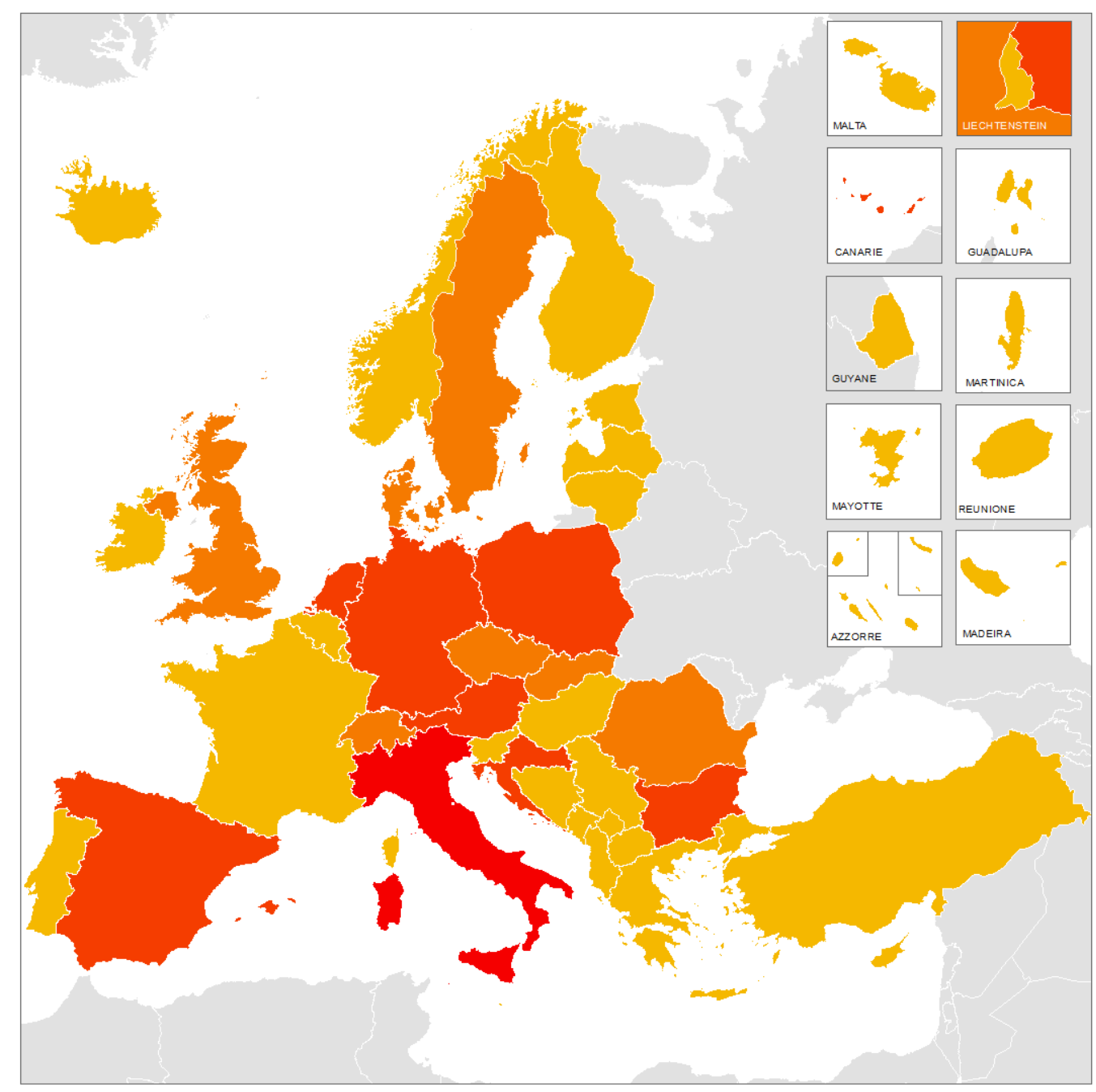

\section{Number of interventions}

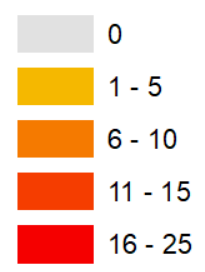

Figure 2. Number of interventions detected in the SUPER project (source: authors' own). 


\section{Results and Discussion}

The adopted methodology makes it possible to analyze the results of the interventions related to the previously introduced categories: scale of interest, type of territory, type of intervention and type of instrument and, for each of them, to identify the degree of success of each intervention with respect to the objective of sustainable urbanization and land use.

Most of the collected interventions (97/227, see Table 3) are designed at a national scale (NUTS0), thus affecting an entire country. In Italy, for example, the National Strategy of Adaptation to Climate Change (2015) provides a vision to address adaptation to climate change, actions and guidelines to develop adaptive capacity and concrete proposals on measures and adaptation priorities. As [14] (p. 771) point out, it also faces the issues of desertification and soil degradation, outlining the measures of protection and mitigation in relation to global warming in relation to the United Nations Framework Convention on Climate Change (UNFCCC). Most of the interventions focus on urban and rural areas (195/227). In Sweden, for example, the Royal Seaport eco-district is considered a very positive urban intervention; in particular, the new neighborhood presents high standards in terms of energy efficiency and sustainability (for more information see [15]). Regarding the type of interventions, most of these are containment (74/227, e.g., the Corona Verde in Italy, the Green Belt in the United Kingdom-for more information see [16,17]), governance $(49 / 227$, for example, the Structural Plan of the Union of Municipalities of Bassa Romagna), densification and regeneration (both 28/227, e.g., the "Gründachstadt Linz" (roof greening of the city of Linz)). The 1984 municipal Green Space Plan of the city of Linz included incentives to increase greening in built-up areas to reduce air pollution. This regeneration intervention is considered successful as it has transformed the city from a post-industrial city to a green and sustainable city and, since 2008 , the city has been officially recognized as a leading green roof city in Austria (for more info see $[18,19]$ ).

Moving on to the tools used, they are mostly strategies (62/227, e.g., the Italian National Strategy for Inner Areas, SNAI, the Austrian 'Vision Rheintal') and legal devices (51/227, e.g., the Environmental Code No. 152/2006, the Montenegrin 2017 Law on Spatial Planning and Construction of Facilities). In particular, the Italian Code on the Environment sets out the legislative framework applicable to all the issues concerning environmental protection. Thus, it is the national regulatory framework for environmental issues, including soil protection, desertification prevention, and hydrogeological risk. The Code represents a major turning point in Italian environmental legislation and aims to harmonize the different environmental sectoral laws (e.g., those relating to waste, water, and air pollution). It is considered to be an effective instrument that promotes long-term sustainable development. Likewise, the Montenegrin 2017 Law on Spatial Planning and Construction of Facilities is deemed to have brought significant innovations in the field of spatial planning and construction. The SNAI (2014), on the other hand, is an Italian national program that aims to provide local strategies to deal with depopulation and the economic weaknesses of some areas in the interior with declining populations. Among the SNAI's various objectives, achieving the sustainability of social, economic, and environmental actions is one of the most important. In the 2014-2020 programming period, many new integrated policies have been applied in rural areas that are distant from the main service centers $(60 \%$ of the national surface area). Like the Environmental Code, the SNAI is recognized as widely successful, but for the moment, the national population does not yet seem to be fully aware of the possibilities the program offers, although it seems to be gaining importance [20]. There are many other ongoing strategies, such as the Vision Rheintal, in the Voralberg region in Austria. The Vision sets the guidelines for long-term socio-economic development in the Rhine Valley, strengthening cooperation beyond municipal boundaries and implementing joint actions to tackle common challenges. For example, it aims to protect natural resources (e.g., creating green corridors) and manage more effectively land-use in the region. For [21] (p. 468), the "use of resilience as a positive vision is useful as a normative foundation of learning and transformative processes". 
Table 3. Number of interventions for analytical category (source: authors' own).

\begin{tabular}{|c|c|c|c|c|c|c|c|c|c|c|c|}
\hline \multirow{11}{*}{$\begin{array}{c}\text { Scale of interest/Geographical } \\
\text { Distribution }\end{array}$} & Type & n. & \multirow{11}{*}{$\begin{array}{l}\text { Type of } \\
\text { territory }\end{array}$} & Type & $\mathrm{n}$. & \multirow{11}{*}{$\begin{array}{c}\text { Type of } \\
\text { intervention }\end{array}$} & Type & $\mathrm{n}$. & \multirow{11}{*}{$\begin{array}{c}\text { Type of } \\
\text { instrument }\end{array}$} & Type & $\mathrm{n}$. \\
\hline & NUTS0 & 97 & & Urban & 125 & & Densification & 28 & & $\begin{array}{l}\text { Legal } \\
\text { device }\end{array}$ & 51 \\
\hline & NUTS1 & 8 & & Rural & 70 & & Containment & 74 & & $\begin{array}{l}\text { Land use } \\
\text { regulation }\end{array}$ & 46 \\
\hline & NUTS2 & 24 & & Functional & 37 & & Regeneration & 28 & & Strategy & 62 \\
\hline & NUTS3 & 39 & & Coastal & 19 & & Governance & 49 & & Program & 21 \\
\hline & LAU1 & 41 & & Mountain & 12 & & $\begin{array}{l}\text { Spatial } \\
\text { quality }\end{array}$ & 19 & & Project & 46 \\
\hline & LAU2 & 36 & & Peripheral & 35 & & Transport & 14 & & Subsidy & 5 \\
\hline & \multirow{3}{*}{ Other } & \multirow{3}{*}{3} & & Cross-border & 16 & & Environment & 14 & & \multirow{3}{*}{ Other } & \multirow{3}{*}{1} \\
\hline & & & & $\begin{array}{c}\text { Scarcely } \\
\text { populated }\end{array}$ & 15 & & $\begin{array}{c}\text { Rural } \\
\text { development }\end{array}$ & 3 & & & \\
\hline & & & & $\begin{array}{c}\text { Other } \\
\text { (nation) }\end{array}$ & 69 & & Other & 17 & & & \\
\hline & Total & $248^{*}$ & & Total & $398^{*}$ & & Total & $246^{*}$ & & Total & $232 *$ \\
\hline
\end{tabular}

* an intervention may concern territories of different categories. 
The subdivision of the collected interventions in the abovementioned analytical categories also allows formulating a number of considerations concerning the effectiveness of the interventions adopted in Europe to promote sustainable use of the land (Table 4). In particular, the degree of success is based on the objective of the intervention, as well as on its sustainability $(1=$ unsuccessful; $2=$ scarcely successful; $3=$ mixed success, $4=$ almost successful; $5=$ successful). As explained in Section 3, the identification of the effectiveness of the interventions was mainly carried out by the collection of data obtained through the online questionnaire, where the experts could evaluate the degree of success of the interventions in terms of sustainable land use. The degree of success described in Section 4.1, Section 4.2, and Section 4.3 is based on the triangulation of this data with the pertinent literature and related research studies.

As regards the scale of interest, $70 \%$ of NUTS3 category interventions proved some sort of effectiveness (grades 4 and 5), while 50\% of category LAU1 interventions report mixed (grade 3) and only $31 \%$ effective results (grades 4 and 5). Of the 227 interventions, $43 \%$ of the urban typology and $50 \%$ of the rural typology are effective at least to some extent (grades 4 and 5). Instead, 33\% of containment interventions are grade 4 and $15 \%$ grade 5 , while $36 \%$ are grade 3 . Governance interventions are fairly effective; $32 \%$ are grades 4 and 5 , and $54 \%$ are grade 3 . Finally, with regards the type of instruments, $49 \%$ of the strategies are effective (grades 4 and 5), while $41 \%$ have mixed results (grade 3 ).

Table 4. Degree of success of the interventions for analytical category (source: authors' own elaboration).

\begin{tabular}{|c|c|c|c|c|c|c|c|}
\hline \multirow{2}{*}{ Type } & & \multicolumn{6}{|c|}{ Degree of Success } \\
\hline & & 1 & 2 & 3 & 4 & 5 & n.a. \\
\hline \multirow{7}{*}{$\begin{array}{c}\text { Scale of interest/geographical } \\
\text { distribution }\end{array}$} & NUTS0 & 14 & 6 & 27 & 21 & 15 & 14 \\
\hline & NUTS1 & 0 & 0 & 4 & 1 & 1 & 1 \\
\hline & NUTS2 & 3 & 1 & 9 & 8 & 2 & 1 \\
\hline & NUTS3 & 2 & 1 & 6 & 14 & 7 & 5 \\
\hline & LAU1 & 5 & 2 & 18 & 5 & 6 & 5 \\
\hline & LAU2 & 6 & 3 & 8 & 7 & 9 & 3 \\
\hline & Other & 0 & 0 & 2 & 0 & 0 & 1 \\
\hline \multirow{9}{*}{ Type of territory } & Urban & 11 & 7 & 43 & 28 & 18 & 18 \\
\hline & Rural & 7 & 3 & 21 & 24 & 7 & 8 \\
\hline & Functional & 5 & 2 & 16 & 8 & 4 & 2 \\
\hline & Coastal & 1 & 1 & 2 & 9 & 3 & 3 \\
\hline & Mountain & 3 & 0 & 4 & 3 & 1 & 1 \\
\hline & Peripheral & 5 & 4 & 10 & 11 & 2 & 3 \\
\hline & Cross-border & 1 & 0 & 8 & 5 & 0 & 2 \\
\hline & Scarcely populated & 2 & 2 & 4 & 4 & 2 & 1 \\
\hline & Other (nation) & 12 & 2 & 20 & 13 & 13 & 9 \\
\hline \multirow{9}{*}{ Type of intervention } & Densification & 3 & 0 & 9 & 9 & 5 & 2 \\
\hline & Containment & 4 & 6 & 24 & 22 & 10 & 8 \\
\hline & Regeneration & 1 & 2 & 5 & 7 & 9 & 4 \\
\hline & Governance & 3 & 2 & 20 & 9 & 3 & 12 \\
\hline & Spatial quality & 4 & 2 & 8 & 3 & 1 & 1 \\
\hline & Transport & 0 & 0 & 5 & 3 & 4 & 2 \\
\hline & Environment & 3 & 0 & 2 & 4 & 3 & 2 \\
\hline & Rural development & 0 & 0 & 0 & 1 & 2 & 0 \\
\hline & Other & 11 & 1 & 3 & 0 & 1 & 1 \\
\hline \multirow{7}{*}{ Type of instrument } & Legal device & 8 & 5 & 17 & 9 & 7 & 5 \\
\hline & Land use regulation & 4 & 1 & 18 & 15 & 4 & 4 \\
\hline & Strategy & 4 & 1 & 21 & 17 & 8 & 11 \\
\hline & Program & 1 & 1 & 7 & 5 & 6 & 1 \\
\hline & Project & 10 & 2 & 8 & 8 & 10 & 8 \\
\hline & Subsidy & 1 & 1 & 0 & 1 & 0 & 2 \\
\hline & Other & 1 & 0 & 0 & 0 & 0 & 0 \\
\hline
\end{tabular}

After these preliminary considerations concerning the statistical distribution of the collected sample in relation to the identified analytical categories and the effectiveness of the interventions, further intersections of these categories were performed, in order to dig more in details on the actual reasons behind their success. The obtained results are discussed in the following subsections. In particular, the analysis first focuses on the interrelations between the category of types of interventions and that of the type tools in order to understand, also considering the degree of success, which are the 
most effective and adequate tools in relation to interventions with different aims. Additional insights are then provided by looking at two other types of interconnections: those between the category of territories and that of tools, and those between the category of territories and that of interventions.

\subsection{The Effectiveness of the Different Types of Instruments in Relation to Different Types of Interventions}

By intersecting the 'type of intervention' category with the 'type of instrument' (Table 5), it is possible to observe the presence of a high number of containment interventions implemented through the adoption of land use regulations (26) or other legal devices (18). For example, the municipality of Cassinetta di Lugagnano (MI) is the first Italian municipality to have approved (in 2007) a zero-growth urban variant, keeping agricultural land intact (for more information see [22]. The number of governance interventions implemented through strategies is also high (24); see, for example, the master plan of the city of Helsinki (2017), which promotes the sustainable growth of the city, enhancing public transport. The city plan provides long-term strategic guidelines and, in order to face future challenges, provides a roadmap for Helsinki's 2050 future growth. For example, since the population is expected to increase by 250,000 new residents, more housing areas are required. As regards the instruments, 17 projects concern urban regeneration (e.g., Reinventing Paris, Dublin Docklands) and seven containment projects. In particular, the Reinventing Paris (Réinventer Paris) project is a current initiative (launched in 2017), which aims to revitalize forgotten areas of the city, in order to guarantee long-term sustainable development. It is considered one of the biggest calls for urban projects at a city level; the city of Paris has been asking urban designers to come up with innovative solutions for unused or under-used city-owned plots, also subterranean (e.g., the ghost metro station of Croix-Rouge). Since the project has been recently launched, it is still too early to evaluate the impacts; however, it is expected to be very promising. In Ireland, the Dublin Docklands regeneration project is considered another positive intervention since it promotes sustainable development and the rehabilitation of brownfield areas (for more information see [23]). This regeneration project is interesting since the transformation can be seen as directly reflective of the shifting dynamics of port facilities, deindustrialization, and the subsequent emergence of the services-based economy. As a deindustrialized site, the Docklands can be seen as encapsulating these shifts, both in terms of function and urban form. On the contrary, the interventions carried out through subsidies are not numerous (only two are linked to containment interventions) and pay little attention to densification strategies, regeneration and environmental policies.

In the light of this first analytical elaboration, it is possible to discuss the impact of the collected interventions and tools further, analyzing whether they are effective or not in a sustainable land use perspective (Table 6). In particular, of the 26 containment interventions implemented through the introduction of land use regulations, 11 are very effective (grades 4 and 5), and 11 have mixed results. In Croatia, for example, the Physical Planning Act (2014) is considered effective because it has promoted the protection of coastal areas and limited the construction of new built-up areas. The Physical Planning Act has led to more harmonization of Croatian regulations with the Protocol on Integrated Mediterranean Coastal Zone Management as regards protected coastal areas, which are considered to be of special interest to the country. The expert providing information for SUPER observed that the intervention is generally successful but that "some adjustments should be made responding to some new trends". In Switzerland, during the 2013 referendum to limit land take, the majority (63\%) of the Swiss population voted in favor of a revised Federal Law on Spatial Planning in order to regulate housing development, preserve the landscape and to reduce urban sprawl (for more information see [24]). This process led to the 2014 revision of the Federal Law of Spatial Planning, which affirms that future development should mainly take place within existing building zones. As a result, both the cantons and the municipalities must adapt their plans to the new Federal provisions. Even if it is still too early to fully evaluate the outcomes of the referendum and of the revised Federal Law on Spatial Planning, the overall process is perceived as successful. Indeed, the respondent describes it as "an innovative decision-making process". Instead, of the 24 governance interventions implemented through strategies, seven are very effective (grades 4 and 5), and 11 present mixed results. In Austria, 
for example, the Vienna urban development plan (STEP) is considered effective, with favorable results in terms of sustainability and quality of life. In particular, the urban development plan (STEP 2005) identified 13 specific 'target areas' of the city that deserved the special attention of urban planners. Ten years of target area management in Vienna seem to have resulted in favorable developments in such areas (e.g., the transformation of the Danube Canal into a recreational area). Thus, the interventions seem to have led to positive policy outcomes in terms of sustainable land use. This management of the city has also enhanced the coordination and collaboration between the interested stakeholders, as well as the consultation between the private and public actors (e.g., municipality, landowners, private developers, planners). In Greece, the master plan of the city of Athens (2014) sets out the strategic guidelines and spatial priorities and addresses the topics of land use conflicts, such as urban sprawl and nature protection (especially in the areas in northern and eastern Attica), as well as climate change issues (for more information on the spatial planning system in Greece, see [25]). However, it is still too early to understand the success of the intervention. In fact, the ESPON interviewer points out that even if the plan "is supposed to be a more sustainable planning direction. It has not been officially evaluated yet."

\subsection{The Effectiveness of Different Types of Instruments towards Different Territories}

By intersecting the 'type of territory' category with that of the 'type of instrument' (Table 7), it is possible to be observed that a high number of interventions are implemented in urban areas through the implementation of strategies (33) and projects (36). For example, the Flemish government has agreed on a 'concrete stop' deal (known as 'betonstop'), a clampdown on consuming open green space for construction projects, whether it concerns housing, industry, or road infrastructure. An interesting instrument offered by the federal planning authority of Lower Austria to their municipalities for pre-assessing the financial costs of rezoning and urban expansion is the 'infrastructural cost calculator' ('Niederösterreichischer Infrastrukturkostenkalkulator'). With this free strategic online planning tool, municipalities are able to pre-assess eventual municipal infrastructural costs and tax revenues that would come with a certain increase in the population [26]. Thus, as a strategic planning instrument, it supports municipalities in financial questions when developing building land. Another interesting example is the Parckfarm project in Belgium, a new model of public space that combines the characteristics of a park and local micro-farming, by transforming former railway lines into a sustainable public park with community activities. The aim of the project is to accustom citizens to agricultural practices in the city, as well as to promote public meetings with neighbors, farmers, designers, and politicians. As regards rural areas, land use regulations (24) and strategies (20) are also high. For example, the Huerta de Valencia spatial plan, one of the ten in-depth case studies of the ESPON SUPER project, aims to preserve more than 11,000 hectares of agricultural land and to recover 250 hectares of orchards and more than 100 traditional buildings. In the case of the Integrated Coastal Zone Management in Malta, the plan provides a framework to stimulate a more concerted and integrated approach to sustainable coastal zone management by involving public and private stakeholders. As can be observed from the table, the interventions carried out through subsidies are not numerous (only three are linked to urban and rural areas). 
Table 5. Intersection of interventions and instruments (source: authors' own).

\begin{tabular}{|c|c|c|c|c|c|c|c|c|}
\hline \multicolumn{2}{|c|}{ Type } & \multicolumn{7}{|c|}{ Type of Instrument } \\
\hline & & Legal Device & Land Use Regulation & Strategy & Program & Project & Subsidy & Other \\
\hline \multirow{9}{*}{ Type of intervention } & Densification & 8 & 9 & 5 & 1 & 5 & 0 & 0 \\
\hline & Containment & 18 & 26 & 15 & 7 & 7 & 2 & 0 \\
\hline & Regeneration & 5 & 2 & 3 & 1 & 17 & 0 & 0 \\
\hline & Governance & 10 & 10 & 24 & 8 & 0 & 1 & 0 \\
\hline & Spatial quality & 8 & 1 & 3 & 3 & 2 & 2 & 0 \\
\hline & Transport & 0 & 0 & 5 & 3 & 6 & 1 & 0 \\
\hline & Environment & 4 & 0 & 5 & 2 & 3 & 0 & 0 \\
\hline & Rural development & 1 & 0 & 1 & 0 & 0 & 1 & 0 \\
\hline & Other & 2 & 0 & 4 & 0 & 10 & 0 & 1 \\
\hline
\end{tabular}

Table 6. Degree of success of interventions and tools (source: authors' own).

\begin{tabular}{|c|c|c|c|c|c|c|c|c|c|c|c|c|c|c|c|c|c|c|c|c|c|c|c|c|c|c|c|c|c|c|c|c|c|}
\hline Type & \multicolumn{6}{|c|}{ Legal Device } & \multicolumn{5}{|c|}{ Land Use Regulation } & \multicolumn{5}{|c|}{ Strategy } & \multicolumn{5}{|c|}{ Program } & \multicolumn{5}{|c|}{ Project } & \multicolumn{5}{|c|}{ Subsidy } & \multicolumn{2}{|c|}{ Other } \\
\hline Densification & & 0 & 2 & 1 & 2 & 0 & 0 & 5 & 3 & 0 & 1 & 0 & 1 & 3 & 0 & 1 & 0 & & 1 & 0 & 0 & 0 & 1 & 1 & 3 & 0 & & 0 & & & 0 & 0 & 0 \\
\hline Containment & & 2 & 7 & 3 & 3 & 2 & $\begin{array}{ll}2 & 1\end{array}$ & 11 & 10 & 1 & 1 & 1 & 2 & 5 & 3 & 3 & 1 & 2 & 2 & 1 & 1 & 0 & 2 & 2 & 2 & 1 & 1 & 0 & 0 & 0 & 1 & 0 & 0 \\
\hline Regene & 0 & 1 & 1 & 1 & 2 & 0 & 0 & 1 & 0 & 1 & 0 & 0 & 1 & 2 & 0 & 0 & 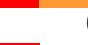 & 0 & & 1 & 0 & 1 & 2 & 4 & 5 & 4 & & 0 & & & 0 & 0 & 0 \\
\hline Governance & 0 & 2 & 4 & 1 & 0 & 3 & 0 & 3 & 1 & 2 & 2 & 0 & 11 & 6 & 1 & 6 & 0 & 3 & 2 & 1 & 1 & & 0 & & & 0 & & 0 & & & 1 & 0 & 0 \\
\hline Spatial quality & & 1 & 2 & 2 & 0 & 1 & 0 & & 1 & 0 & 0 & 0 & 3 & 0 & & 0 & 0 & 3 & 0 & & 0 & 0 & 0 & 0 & 1 & 0 & 1 & & 0 & & 0 & 0 & 0 \\
\hline Transport & & & 0 & & & 0 & & 0 & & & 0 & 0 & 2 & 1 & 2 & 0 & 0 & 1 & 0 & 2 & 0 & 0 & 3 & 2 & 0 & 1 & & 0 & & & 1 & 0 & 0 \\
\hline Environment & & 0 & 1 & 1 & 1 & 0 & & 0 & & & 0 & 0 & 1 & 1 & 1 & 1 & 0 & & 1 & 1 & 0 & & 0 & 1 & 0 & 1 & & 0 & & & 0 & 0 & 0 \\
\hline Rural development & & $c$ & & & 1 & 0 & & 0 & & & 0 & 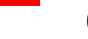 & b & & 1 & 0 & & 0 & & & 0 & & 0 & & & 0 & 0 & & 1 & 0 & 0 & 0 & 0 \\
\hline Other & & 0 & 1 & & & 0 & & 0 & & & 0 & 0 & 1 & 0 & 1 & 0 & & 0 & & & 0 & 1 & 1 & 0 & & 1 & & 0 & & & 0 & 0 & 0 \\
\hline
\end{tabular}

The colors of the cells represent the degree of success: Red = unsuccessful; Orange $=$ scarcely successful; Yellow = mixed success; Light green = almost successful; Dark green = successful; Grey = not applicable. 
Further considerations concerning the impact of the interventions presented in Table 7 may be developed, when considering their degree of success in relation to sustainable land use (see Table 8). In particular, of the 33 strategies implemented in urban areas, 13 are held to be very effective (grades 4 and 5), and 13 have mixed results. In Italy, for example, the municipal, structural plan of the Union of Municipalities of Bassa Romagna (Unione dei Comuni della Bassa Romagna) is considered a good instrument that contrasts urban sprawl and supports sustainable development. The 9 Municipalities of the Union of the Municipalities of Bassa Romagna (Alfonsine, Bagnacavallo, Bagnara di Romagna, Conselice, Cotignola, Fusignano, Lugo, Massa Lombarda and Sant'Agata sul Santerno) have adopted the PSC (Piano Strutturale Comunale) to promote coherent spatial planning throughout the entire territory. Like the Huerta de Valencia spatial plan, the municipal, structural plan of the Union of Municipalities of Bassa Romagna is one of the 10 case studies (see Section 2) chosen by the SUPER project, in order to carry more in-depth analysis (with the help of interviews) and to understand whether the different planning practices are carried out in a sustainable perspective, as well as the degree of efficiency of inter-municipal local plans in terms of sustainable land use. In Denmark, the 2019 revision of the well-known Finger Plan in Copenhagen is another interesting containment intervention, which started in 2016, after a period of public consultation (34 municipalities of the region were also involved). The aim of the plan, originally created in 1947, was to control unregulated development and protect the countryside, as well as to reduce urban sprawl (for more information see [27-30]). Nevertheless, the expert providing information for SUPER observed that the 2019 revision is "likely to reduce the amount of green space in the Greater Copenhagen area".

Of the 36 projects implemented in urban areas, 15 are very effective (grades 4 and 5), and 7 present mixed results. The Bologna Local Urban Environment Adaptation Plan for a Resilient City (BLUE AP) project was created in 2012, with the aim of providing the city of Bologna with a climate change adaptation plan, in order to make the city less vulnerable and to be able to act in case of floods, droughts and other consequences of climate change. The planning and experimentation work carried out with BLUE AP in the city of Bologna will allow the realization of guidelines, which could also be used by other cities that intend to develop similar adaptation plans. The BLUE AP is a European project funded by the LIFE + program (LIFE11 ENV/IT/119), the Community financial instrument whose main objective is to provide specific support to the measures necessary to achieve the objectives set by the Sixth Environmental Action Program. Launched on 1 October 2012 and ended on 30 October 2015, BLUE AP was coordinated by the Municipality of Bologna and involved, as partners, the Kyoto Club, Ambiente Italia, and the ARPA Emilia Romagna. The intervention is seen as successful since it promotes climate change adaptation measures and urban resilience; the interviewer also believes that it has also led to the creation of other sustainable plans, such as the mobility one. In Bulgaria and Serbia, in the cross-border region of Kyustendil-Surdulica, the 2007-2013 project 'Green cross-border area-Investment in nature' is recognized as a positive intervention, since it promotes sustainable cross-border development, environmental education and awareness (e.g., creation of an information center for environmental protection in Vlasina), as well as the exchange of good practices and information (e.g., through public activities and events). The intervention is also considered to be successful, as it promotes the preservation and maintenance of the existing natural resources in urban and protected areas, to ensure sustainable social and economic development in the cross-border region. The possibility to combine a strategic vision with more detailed and tailored initiatives has contributed to the restoration of the area for outside activities in Kyustendil, as well as raising the knowledge of a more active and friendly environmental approach. 
Table 7. Intersection of type of territory and instruments (source: authors' own).

\begin{tabular}{|c|c|c|c|c|c|c|c|c|}
\hline & \multirow{2}{*}{ Type } & \multicolumn{7}{|c|}{ Type of Instrument } \\
\hline & & Legal Device & Land Use Regulation & Strategy & Programm & Project & Subsidy & Other \\
\hline \multirow{8}{*}{ Type of territory } & Urban & 18 & 25 & 33 & 12 & 36 & 3 & 1 \\
\hline & Rural & 11 & 24 & 20 & 7 & 8 & 3 & 0 \\
\hline & Coastal & 2 & 5 & 1 & 2 & 8 & 1 & 0 \\
\hline & Mountain & 4 & 0 & 2 & 1 & 4 & 2 & 0 \\
\hline & Peripheral & 6 & 7 & 7 & 4 & 9 & 3 & 0 \\
\hline & Cross-border & 3 & 0 & 4 & 2 & 7 & 0 & 0 \\
\hline & Scarcely populated & 2 & 2 & 2 & 4 & 3 & 2 & 0 \\
\hline & Other (nation) & 30 & 12 & 21 & 6 & 1 & 1 & 0 \\
\hline
\end{tabular}

Table 8. Degree of success of type of territory and instruments (source: authors' own).

\begin{tabular}{|c|c|c|c|c|c|c|c|c|c|c|c|c|c|c|c|c|c|c|c|c|c|c|c|c|c|c|c|c|c|c|c|c|c|c|c|c|c|c|}
\hline Type & \multicolumn{6}{|c|}{ Legal Device } & \multicolumn{6}{|c|}{ Land Use Regulation } & \multicolumn{5}{|c|}{ Strategy } & \multicolumn{7}{|c|}{ Program } & \multicolumn{5}{|c|}{ Project } & \multicolumn{7}{|c|}{ Subsidy } & \multicolumn{2}{|c|}{ Other } \\
\hline Urban & & 2 & 9 & 3 & 2 & 1 & 1 & 1 & 12 & 6 & 2 & 3 & & 1 & 13 & 10 & 3 & 5 & & 1 & 3 & 2 & 4 & 1 & & 1 & 7 & 7 & 8 & 7 & 0 & 1 & & 0 & & 2 & 0 & 0 \\
\hline Rural & & 0 & 6 & 1 & 1 & 1 & 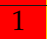 & 1 & 9 & 9 & 2 & 2 & & 1 & 5 & 6 & 3 & 4 & 0 & ) & 3 & 3 & 1 & 1 & & 0 & j & 4 & 1 & 0 & 0 & 1 & 0 & 1 & 0 & 1 & 0 & 0 \\
\hline Functional & 0 & 1 & 5 & 2 & 0 & 0 & 0 & b & 4 & 1 & 0 & 0 & & 0 & 2 & 5 & 1 & 0 & & 0 & 1 & 0 & 1 & 0 & & 1 & 4 & 0 & 2 & 2 & & & 0 & & & 0 & 0 & 0 \\
\hline Coastal & 0 & & 1 & 1 & 0 & 0 & & 0 & & 5 & 0 & 0 & & 0 & & 1 & 0 & 0 & & 0 & & 1 & 1 & 0 & & 1 & 1 & 0 & 3 & 3 & & 0 & & 1 & 0 & 0 & 0 & 0 \\
\hline $\mathrm{Mc}$ & & 0 & 2 & 0 & 1 & 0 & & & 0 & & & 0 & 0 & & 1 & 2 & 0 & 0 & & & 0 & & & 1 & & 0 & 1 & 1 & 0 & 0 & & 0 & & 1 & 0 & 1 & 0 & 0 \\
\hline Perip & 0 & & 4 & 1 & 0 & 1 & 0 & 1 & 2 & 4 & 0 & 0 & & 0 & 2 & 3 & 1 & 0 & 0 & 1 & 2 & 1 & 0 & 1 & & 1 & 1 & 1 & 1 & 1 & 0 & 1 & 0 & 1 & 0 & 1 & 0 & 0 \\
\hline Cross-border & 0 & & 3 & c & 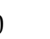 & 0 & & & 0 & & & 0 & 0 & & 2 & 1 & 0 & 1 & 0 & & 2 & 1 & 0 & 0 & & 0 & 2 & 3 & 0 & 1 & & & 0 & & & 0 & 0 & 0 \\
\hline Scarcely populated & & & & J & & 1 & 0 & b & 3 & 0 & & 0 & 0 & & 1 & 0 & 1 & 0 & 0 & 1 & 1 & 2 & 0 & 0 & & 0 & ) & 1 & 1 & 0 & 0 & 1 & 0 & 1 & 0 & 0 & 0 & 0 \\
\hline Other (nation) & & 2 & 8 & 6 & 5 & 3 & & 0 & 4 & 3 & 1 & 1 & & 0 & 6 & 4 & 4 & 5 & 0 & & 3 & 1 & 2 & 0 & & 0 & ) & & 1 & 0 & & & 0 & 0 & & 0 & 0 & 0 \\
\hline
\end{tabular}

The colors of the cells represent the degree of success: Red $=$ unsuccessful; Orange $=$ scarcely successful; Yellow $=$ mixed success; Light green $=$ almost successful; Dark green $=$ successful; Grey = not applicable. 


\subsection{The Effectiveness of Different Types of Interventions towards Different Territories}

By intersecting the 'type of territory' category with the 'type of intervention' (Table 9), it is possible to observe the presence of a high number of containment interventions in urban (40) and rural (32) areas. For example, green belts and comparable regional concepts of green area development have been developed in Germany (e.g., the Grüner Ring in Leipzig, the regional parks in Berlin), which have been strengthened by informal visions, strategies and intercommunal cooperation (for more details see [31]). Governance interventions are quite high in both urban (29) and rural areas (20). Regeneration (21) and densification (18) interventions are also frequent in urban areas, whereas in rural areas, a smaller number of these types of interventions can be found (for the four interventions). For example, the community-led regeneration process in Casoria (Italy) is perceived as a very successful project, since it has a long-term strategy that aims to minimize the impact of abandoned areas on citizens. The 2013-2018 project had two main objectives: the rehabilitation of abandoned areas and the enhancement of public participation. In particular, the project implemented a series of small interventions in line with the broader urban strategy. From the outset, for example, owners of key brownfield sites were asked to provide temporary public paths on their land to connect future regeneration sites directly with the city center. Nevertheless, certain types of interventions (e.g., rural development, environment, and transport) are not too frequent, especially in the mountain, scarcely populated, and cross-border areas.

After these preliminary considerations, it is interesting to analyze further the impact of the interventions presented in Table 9, as well as their effectiveness and degree of success in terms of sustainable land use (Table 10). In particular, of the 40 containment interventions implemented in urban areas, 13 are very effective (grades 4 and 5) and 15 have mixed results. In Switzerland, for example, the Swiss Agglomeration Programs are considered to be successful. Around 40 agglomerations throughout the country have established a program that enables them to harmonize their transportation, urban development, and land-use plans better, and thereby to take part in federal programs for funding transportation-related infrastructure projects. In the interest of promoting sustainable development, the Swiss government has adopted an agglomeration policy that encourages agglomerations to draft their own transportation and urban development programs. According to the interviewer, thanks to a dedicated national budgetary contribution, the initiative is "generating high interest and seems to further strengthen cooperation across borders within functional areas". Of the 29 governance interventions implemented in urban areas looked at in the SUPER survey, eight are very effective (grades 4 and 5), and 14 present mixed results. In Finland, for example, the 14 municipalities of the Helsinki region and the state have signed agreements on land use, housing, and transport (MAL) for the 2016-2019 period. These MAL agreements enhance cooperation among the municipalities in the respective city regions and between the municipalities and the state in the steering of community infrastructure and coordination of land use, housing, and transport. The aim is to achieve more functional and competitive urban regions and balanced development of the municipalities. The intervention is widely perceived as successful since it promotes a more effective land use management and future sustainable development. The MAL agreements specify, for example, the shared regional objectives for land use and housing production in the coming years and delineate the key development projects concerning the transport network. In Poland, the 2016 planning law and housing policy of the Warsaw metropolitan area is considered a positive intervention which aims to improve the spatial structure of both the city and its surrounding area, in the light of long-term sustainable development (e.g., introducing green corridors, protecting green areas, reducing sprawl). The intervention is, therefore, deemed to be successful. Nevertheless, the expert points out that the intervention has "good potential but needs time". 7 of the 20 governance interventions implemented in rural areas are, according to the SUPER informants, very effective (grades 4 and 5), and 7 present mixed results. 
Table 9. Intersection of type of territory and intervention (source: authors' own).

\begin{tabular}{|c|c|c|c|c|c|c|c|c|c|c|}
\hline \multirow{2}{*}{\multicolumn{2}{|c|}{ Type }} & \multicolumn{9}{|c|}{ Type of Intervention } \\
\hline & & Densification & Containment & Regeneration & Governance & Spatial Quality & Transport & Environment & Rural Development & Other \\
\hline \multirow{8}{*}{ Type of territory } & Urban & 18 & 40 & 21 & 29 & 8 & 9 & 6 & 0 & 7 \\
\hline & Rural & 4 & 32 & 4 & 20 & 4 & 3 & 4 & 2 & 4 \\
\hline & Functional & 2 & 12 & 6 & 8 & 2 & 5 & 2 & 1 & 5 \\
\hline & Coastal & 2 & 6 & 1 & 2 & 1 & 2 & 1 & 1 & 3 \\
\hline & Mountain & 0 & 3 & 0 & 4 & 1 & 2 & 1 & 2 & 1 \\
\hline & Peripheral & 0 & 17 & 1 & 9 & 6 & 3 & 0 & 2 & 4 \\
\hline & Cross-border & 0 & 5 & 1 & 8 & 0 & 5 & 2 & 0 & 0 \\
\hline & Scarcely populated & 0 & 8 & 3 & 2 & 3 & 0 & 2 & 2 & 0 \\
\hline
\end{tabular}

Table 10. Degree of success of type of territory and interventions (source: authors' own).

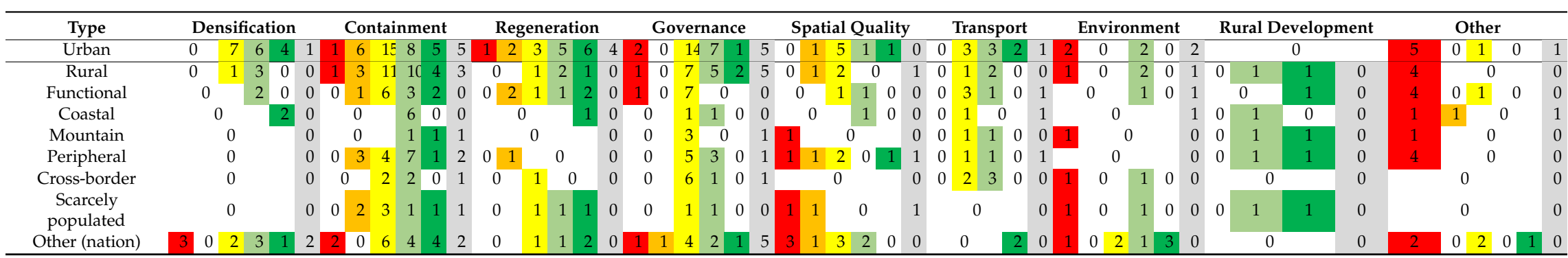

The colors of the cells represent the degree of success: Red = unsuccessful; Orange $=$ scarcely successful; Yellow = mixed success; Light green = almost successful; Dark green $=$ successful; Grey = not applicable. 
Of the 32 containment interventions implemented in rural areas, 14 are very effective (grades 4 and 5), and 11 have mixed results. In Austria, for example, the 2014 regional master plan ('Regionaler Leitplan-Bezirk Mödling') was drawn up on the initiative of the 20 communities of Mödling, together with the support of the Province of Lower Austria, the representatives of the communities and experts from the planning department of the Province of Lower Austria. The plan is considered a useful instrument in promoting and coordinating sustainable spatial development sustainable land use in a region with 20 different communities (for more information see [32]). The expert providing information for SUPER observed that the guiding principles for spatial development were formulated for the following: urban development: 'growth yes, but controlled and steered'; green and open space: 'protect, use, connect, design'; and mobility: 'modal split in favor of sustainable transport modes'. The expert considers the plan successful since it "promotes and coordinates sustainable spatial development". As mentioned previously, the Corona Verde ('Green Crown') is another interesting intervention, located in Italy. The goal of this intervention is to bring together intersectoral policies (e.g., nature, landscape and cultural heritage), creating a new and alternative vision of the territory, based on the quality of the environment and quality of life. The strategy envisages an ecological crown for the metropolitan area of Torino, which includes over 80 municipalities. The interviewer considers the intervention successful and observes that the "strategy has been implemented, and several funds have been invested in order to increase the level of sustainability". The results are varied and heterogeneous, and include the improvement of the accessibility of parks, the maintenance of scenic routes, the mitigation and renaturation of infrastructural barriers, the landscaping of green spaces in the rural-urban interface, and the conservation of the rural heritage. The Corona Verde is considered a positive intervention since it contributes to reducing urban land consumption and to increase the quality of the rural-urban environment (for more detail, see [33]).

\section{Concluding Remarks and Future Research Perspectives}

The paper aimed at providing an overview of the interventions put in place in recent years in Europe, aiming at achieving more sustainable use of the land. To do so, it built on some of the results of the ESPON SUPER project, and in particular, on a database of 227 interventions collected from experts active in as many as 39 European countries. The interventions were at first categorized according to four main analytical variables and then assessed in relation to their actual degree of success. Moreover, further elaborations were produced, in order to discuss more in-depth (i) the appropriateness of the various instruments in relation to different types of interventions, (ii) the effectiveness of the various instruments in relation to different types of territories and (iii) the effectiveness of the various types of interventions towards different types of territories

First and foremost, the analysis shows that the degree of success of the examined interventions and, therefore, of their ability to direct the use of the land towards a more sustainability perspective varies according to four main elements. Firstly, it depends on the scale of interest, and thus on the administrative level of implementation. Whereas certain interventions seem to be more effective if adopted locally (e.g., regulations), some national strategies seem much more effective than local ones. Secondly, it varies according to the type of territory included in their scope, as an initiative that works in an urban or peri-urban area does not necessarily produce the same effects if implemented in a remote mountain or rural territory. Thirdly, it varies according to the type of interventions at stake, with some interventions that generally seem to achieve a good degree of success (e.g., those focusing on containment, densification and urban regeneration), while others are less useful for sustainable land management (as for instance those insisting on spatial quality). Fourthly, it varies according to the type of instruments: some types of initiatives (e.g., legal devices, regulations, and strategies) are more successful than others (e.g., subsidies or projects) that seem to have mixed effects.

From the interaction of the analyzed variables, and in particular, exploring the degree of success of the different types of interventions in relation to the various types of instruments, it is interesting to observe that, in order to promote densification initiatives, it seems preferable to operate in terms of legal 
arrangements, land use regulations and projects (e.g., fiscal taxation in Italy, the Physical Planning Act in Croatia, the Royal Seaport in Stockholm). In Italy, despite not being the objective of the initiative per se, the increasing of taxation of private properties pushed landowners to require the conversion of their plots from buildable to agricultural areas (which are exempted from paying additional taxation), in so doing favoring policy-makers in the incremental reduction of soil consumption allowed by the local regulatory planning instruments. On the contrary, interventions involving the implementation of programs and the preparation of subsidies and incentives seem only partially successful (e.g., housing arrangements in Croatia). Similarly, to promote urbanization containment, it seems that better results are obtained through initiatives that include the introduction of dedicated regulations, accompanied by the activation of strategies in this regard (e.g., Vision Rheintal in Austria, Corona Verde in Italy). Finally, to promote regenerative initiatives, it appears to be more effective to focus on the implementation of projects supported by a clear legislative and strategic framework (e.g., brownfield targets in the United Kingdom, urban rehabilitation areas in Portugal).

When looking at the degree of success of the various types of instruments in relation to different types of territories, it is interesting to observe, through the lenses of sustainability, that most of the reported interventions concerns urban and rural areas; whereas coastal, mountain, peripheral, cross-border and scarcely populated areas seem to be interested in a lower number of interventions. According to the results of the analysis, the degree of success of the interventions carried out in these 'more fragile' areas (and especially in mountain and scarcely populated areas) appear to be the highest when they are implemented through projects, land use regulations and strategies (e.g., the 'Green cross-border area-Investment in nature' project in the cross-border area between Bulgaria and Serbia). Therefore, these fragile areas need more effective strategies and programs that specifically promote sustainable land use. The majority of instruments appear to be strategies and projects (especially in urban and rural areas, e.g., the infrastructural cost calculator in Austria, the Parckfarm project in Belgium); legal devices and land use regulations are also quite frequent (e.g., the general local plan in Albania, the 65/2014 regional law on soil consumption in Tuscany), whereas programs and subsidies are less common (e.g., the BENE-Berlin Program for Sustainable Development in Germany). As discussed in Section 4.2, the interventions that appear to be more successful (see Table 8) are those implemented through strategies (e.g., the urban development plan in Vienna, the high-density urban expansion in the Netherlands) and projects (e.g., the Bologna Local Urban Environment Adaptation Plan for a resilient city, the Dublin Docklands in Ireland).

Finally, observing the interactions between the 'type of territory' and 'type of intervention', and analyzing their degree of success, it is interesting to note that, also, in this case, most of the interventions are located in urban and rural areas; whereas coastal, mountain, peripheral, cross-border and scarcely populated areas present a minor number of interventions. The majority of the interventions appear to be those of containment and of governance (especially in urban and rural areas); regeneration and densification interventions are also frequent. On the contrary, there seem to be fewer densification, regeneration, spatial quality, transport, environmental, and rural development interventions. The interventions that have been carried out in urban and rural areas that appear to be more successful are those implemented through containment and governance policies (e.g., the agglomeration programs in Switzerland, the planning law, and housing policy of the Warsaw metropolitan area). Also, in this regards, coastal, mountain, peripheral, cross-border, and scarcely populated areas, the interventions that seem to be more positive are those carried through containment programs (e.g., the Huerta de Valencia Spatial Plan in Spain, the Integrated Coastal Zone Management in Malta).

In conclusion, from this preliminary analysis, it can be argued that, since there is no instrument perfectly adaptable to any context, the effectiveness of the interventions aimed at a sustainable use of land depends on the differential interaction of the variables described above, and in particular of the scale of its adoption, the instrument(s) it utilizes and the type of territory it concerns. This is in line with a number of academic contributions focusing on the actual transferability of spatial policies 
that highlight the complexity of the processes of 'filtering in' and 'filtering out' that characterize the latter [34]. In this regard, an interesting direction for future research could concern the further contextualization of the instruments examined in this contribution within a wider typology of spatial governance systems in Europe $[4,35]$. These would be compiled, on the one hand, in relation to the capacity for public control over spatial development guaranteed by each of them and, on the other, by the effective sustainability of the results produced in the various contexts in terms of land use. Future studies should also focus more on the factors that govern the success or lack of success of a particular practice. Finally, additional considerations should be developed in relation to the role that the European Union has been playing in recent years in the promotion of an Agenda aimed at a more sustainable urban development, and how the latter has produced any influence in this concern in the member countries [36,37].

Author Contributions: G.C. and U.J.R. designed the project and supervised its implementation. E.B. and A.S. carried out data collection and analysis. All sections of the paper were written and revised by all four authors. All authors have read and agreed to the published version of the manuscript.

Funding: The research was carried out as part of the ESPON SUPER 2019-2020 project (https://www.espon.eu/ super).

Acknowledgments: The research project SUPER (Sustainable Urbanization and Land-Use Practices in European Regions) is carried out within the framework of the European Territorial Observatory Network (ESPONhttps://www.espon.eu/). The consortium responsible for the project is coordinated by PBL (the Dutch Environmental Agency) and composed of Politecnico di Torino, BBSR (German Federal Institute for Research on Building, Urban Affairs, and Spatial Development), OIR (Austrian Institute for Regional Studies and Spatial Planning), University of Valencia, University of Warsaw and Urbanex. Additional information concerning the project are available at: https://www.espon.eu/super. The authors would like to thank all the members of the ESPON SUPER team for their proactive cooperation throughout the project. Similarly, they express their gratitude to Donato Casavola for his assistance in the data collection process.

Conflicts of Interest: The authors declare no conflict of interest.

\section{References}

1. ESPON EU-LUPA—European Land Use Patterns; Applied Research 2013/1/8, (Part B) Final Report, Version 7/February/2014; ESPON EGTC: Luxembourg, 2014.

2. Munafò, M. (Ed.) Consumo di suolo, dinamiche territoriali e servizi ecosistemici, Edizione 2019; Report SNPA 08/19; Istituto Superiore per la Protezione e la Ricerca Ambientale: Rome, Italy, 2019.

3. Hartmann, T.; Gerber, J.-D. Land, scarcity, and property rights. In Instruments of Land Policy: Dealing with Scarcity of Land; Gerber, J.-D., Hartmann, T., Hengstermann, A., Eds.; Taylor \& Francis: Abingdon, Oxon, 2018; pp. 3-7.

4. Cotella, G.; Janin Rivolin, U.; Berisha, E.; Solly, A. Sistemi di governo del territorio e controllo pubblico delle trasformazioni spaziali: Una tipologia europea. Territorio 2020, in press.

5. Janin Rivolin, U. Global crisis and the systems of spatial governance and planning: A European comparison. Eur. Plan. Stud. 2017, 25, 994-1012. [CrossRef]

6. Cotella, G.; Othengrafen, F.; Papaioannoua, A.; Tulumello, S. Socio-political and socio-spatial impacts of the crisis in European cities and regions. In Cities in Crisis. Reflections on the socio-spatial impacts of the economic crisis and the strategies and approaches applied by Southern European cities; Knieling, J., Othengrafen, F., Eds.; Routledge: London, UK, 2015; pp. 27-47.

7. Janin Rivolin, U. Planning Systems as Institutional Technologies: A Proposed Conceptualization and the Implications for Comparison. Plan. Pract. Res. 2012, 27, 63-85. [CrossRef]

8. ESPON COMPASS-Comparative Analysis of Territorial Governance and Spatial Planning Systems in Europe; Applied Research 2016-2018, Final Report; ESPON EGTC: Luxembourg, 2018.

9. Nadin, V.; Stead, D. European Spatial Planning Systems, Social Models and Learning. Disp-Plan. Rev. 2008, 44, 35-47. [CrossRef]

10. Cotella, G.; Stead, D. Spatial Planning and the Influence of Domestic Actors: Some Conclusions. Disp-the Plan. Rev. 2011, 47, 77-83. [CrossRef] 
11. Tulumello, S.; Cotella, G.; Othengrafen, F. Spatial planning and territorial governance in Southern Europe between economic crisis and austerity policies. Int. Plan. Stud. 2020, 25, 72-87. [CrossRef]

12. ESPON SUPER-Sustainable urbanization and land use practices in the European Regions; Applied Research, Inception Report; ESPON EGTC: Luxembourg, 2019.

13. ESPON SUPER-Sustainable urbanization and land use practices in the European Regions; Applied Research, Interim Report; ESPON EGTC: Luxembourg, 2020.

14. Ronchi, S.; Salata, S.; Arcidiacono, A.; Piroli, E.; Montanarella, L. Policy instruments for soil protection among the EU member states: A comparative analysis. Land Use Policy 2019, 82, 763-780. [CrossRef]

15. Holmstedt, L.; Brandt, N.; Robèrt, K.-H. Can Stockholm Royal Seaport be part of the puzzle towards global sustainability? - From local to global sustainability using the same set of criteria. J. Clean. Prod. 2017, 140, 72-80. [CrossRef]

16. Amati, M.; Yokohari, M. Temporal changes and local variations in the functions of London's green belt. Landsc. Urban Plan. 2006, 75, 125-142. [CrossRef]

17. Amati, M.; Taylor, L. From Green Belts to Green Infrastructure. Plan. Pract. Res. 2010, 25, 143-155. [CrossRef]

18. Hansen, R. Linz, Austria-Case Study City Portrait; APPENDIX-GREEN SURGE Study on Urban Green Infrastructure Planning and Governance in 20 European Cities; University of Copenhagen: Copenhagen, Denmark, 2015; pp. 165-175.

19. Schroepfer, T.; Limin, H. Emerging Forms of Sustainable Urbanism: Case Studies of Vauban Freiburg and solarCity Linz. J. Green Build. 2008, 3, 65-76. [CrossRef]

20. Cotella, G.; Vitale Brovarone, E. The Italian National Strategy for Inner Areas: A Place-Based Approach to Regional Development. In Dilemmas of Regional and Local Development; Routledge: London, UK, 2020; pp. 50-71.

21. Abeling, T.; Daschkeit, A.; Mahrenholz, P.; Schauser, I. Resilience-A Useful Approach for Climate Adaptation? In Urban Disaster Resilience and Security: Addressing Risks in Societies; Fekete, A., Friedrich, F., Eds.; Springer: Cham, Switzerland, 2018; pp. 461-472.

22. Boatti, A. La pianificazione urbanistica in Lombardia alla prova dei piccoli comuni. Due "comuni virtuosi". Territorio 2009, 49, 74-80.

23. Byrne, M. Entrepreneurial Urbanism after the Crisis: Ireland's "Bad Bank" and the Redevelopment of Dublin's Docklands. Antipode 2016, 48, 899-918. [CrossRef]

24. Solly, A. Spatial Planning and Well-being: A Survey on the Swiss Case; Politecnico di Torino: Torino, Italy, 2018.

25. Asprogerakas, E.; Zachari, V. The EU territorial cohesion discourse and the spatial planning system in Greece. Eur. Plan. Stud. 2019, 1-21. [CrossRef]

26. Humer, A.; Sedlitzky, R.; Brunner, D. When does population growth pay off? A case study of suburban land consumption to assess the Lower Austrian infrastructural cost calculator. J Hous. Built Environ. 2019, 34, 331-344. [CrossRef] [PubMed]

27. Caspersen, O.H.; Konijnendijk, C.C.; Olafsson, A.S. Green space planning and land use: An assessment of urban regional and green structure planning in Greater Copenhagen. Geogr. Tidsskr. Dan. J. Geogr. 2006, 106, 7-20. [CrossRef]

28. Knowles, R.D. Transit Oriented Development in Copenhagen, Denmark: From the Finger Plan to Ørestad. J. Transp. Geogr. 2012, 22, 251-261. [CrossRef]

29. Brüel, M. Copenhagen, Denmark: Green City amid the Finger Metropolis. In Green Cities of Europe: Global Lessons on Green Urbanism; Beatley, T., Ed.; Island Press/Center for Resource Economics: Washington, DC, USA, 2012; pp. 83-108.

30. Caspersen, O.H.; Olafsson, A.S. Recreational mapping and planning for enlargement of the green structure in greater Copenhagen. Urban Forest. Urban Green. 2010, 9, 101-112. [CrossRef]

31. von Haaren, C.; Reich, M. The German way to greenways and habitat networks. Landsc. Urban Plan. 2006, 76, 7-22. [CrossRef]

32. Klinger, S.; Krassnitzer, P.; Zech, S. Regionaler Leitplan Bezirk Mödling. In Mödling: Gemeindeverband für Abgabeneinhebung und Umweltschutz; University of Vienna: Vienna, Austria, 2016.

33. Cassatella, C. The 'Corona Verde' Strategic Plan: An integrated vision for protecting and enhancing the natural and cultural heritage. Urban Res. Pract. 2013, 6, 219-228. [CrossRef] 
34. Cotella, G.; Janin Rivolin, U.; Santangelo, M. Transferring good territorial governance in Europe: Opportunities and barriers. In Territorial governance across Europe: Pathways, practices and prospects; Schmitt, P., Van Well, L., Eds.; Routledge: London, UK, 2016; pp. 238-253.

35. Berisha, E.; Cotella, G.; Janin Rivolin, U.; Solly, A. Spatial governance and planning systems and the public control of spatial development: A European typology. Eur. Plan. Stud. 2020; in press.

36. Cotella, G. The Urban Dimension of EU Cohesion Policy. In Territorial Cohesion, The Urban Dimension; Springer: Cham, Switzerland, 2019; pp. 133-151.

37. Adams, N.; Cotella, G.; Nunes, R.J. Spatial planning in Europe: The interplay between knowledge and policy in an enlarged EU. In Territorial Development, Cohesion and Spatial Planning, Knowledge and Policy Development in an Enlarged EU; Adams, N., Cotella, G., Nunes, R.J., Eds.; Routledge: London, UK, 2011; pp. 1-25.

(C) 2020 by the authors. Licensee MDPI, Basel, Switzerland. This article is an open access article distributed under the terms and conditions of the Creative Commons Attribution (CC BY) license (http://creativecommons.org/licenses/by/4.0/). 